\title{
Freshwater ecosystems in oceanic islands of Chile: Conservation of endemic microfauna and the role of exotic species in the biological control of tropical diseases
}

Ecosistemas acuáticos de islas oceánicas de Chile: Conservación de microfauna endémica y el rol de especies exóticas en el control biológico de enfermedades tropicales

PATRICIO R. DE LOS RÍOS-ESCALANTE

\begin{abstract}
Escuela de Ciencias Ambientales, Facultad de Recursos Naturales, Universidad Católica de Temuco, Casilla 15-D, Temuco, Chile e-mail: prios@uct.cl
\end{abstract}

The presence of tropical diseases transmitted by mosquitoes mainly of the genus Aedes has been reported for Polynesia (Lardeaux 1992, Lardeaux et al. 1992), Eastern Island (Olea 2003), and also tropical latitudes of Latin America in the case of "dengue" (Laval 2003). Thus, some exotic species have been introduced to serve as biological controllers, such as the fish Gambussia affinis (Baird \& Girard, 1853) in continental Chile (Dyer 2000, Iriarte et al. 2005), and Mesocyclops aspericornis (Daday, 1906) in French Polynesia (Lardeaux 1992, Lardeaux et al. 1992). The Chilean oceanic islands have numerous water bodies that may favor the presence of mosquitoes, such as small lakes in Eastern Island (Dumont \& Martens, 1995), and small streams in Juan Fernandez islands (Brehm 1937). Recently, the presence of an isolated case of "dengue" in Eastern Island (Olea 2003) has motivated the use of biological control by introducing Gambussia affinis in small lakes (Dumont \& Verschuren 1991, Magliulo-Cepriano et al. 2003). Although this species has been described as an active predator and an efficient biological controller of mosquitoes, its introduction conveys the risk of increased predation on zooplankton and littoral microinvertebrates (Leyse et al. 2005). In this context, the microfauna of Eastern Island includes particular microcrustacea such as the cladoceran Alona weinecki (Stüder, 1878) and the ostracod Sarscypridopsis sp., restricted to Eastern Island and the subAntarctic islands Southern Georgia, Falkland, South Orkneys, Kerguelen, Heard Islands, Marion and
Macquarie Islands, and also relatively cosmopolitan species such as the copepod Paracyclops fimbriatus (Fisher, 1853) and the ostracods Heterocypris incongruens (Ramdohr, 1808) and Cypretta seurati (Gauthier, 1829) (see Dumont \& Martens 1996). Biological control may thus generate a conservation problem affecting these microinvertebrate species, considering the case of continental Chile where G. affinis occurs between $23^{\circ}$ and $33^{\circ} \mathrm{S}$ (Iriarte et al. 2005), and its predatory behavior could reduce the abundance of microinvertebrates, as observed in zones of the Loa river such as

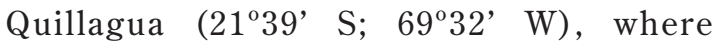
crustaceans do not occur in zones with abundant $G$. affinis populations (De los Ríos et al. 2010). In this regard, the absence or low abundance of microinvertebrates in the presence of $G$. affinis was also noted in recent field surveys in the lake located at the Rano Kau crater volcano (De los Ríos, personal observation June 5, 2010). Such observations would be in conflict with a previous study of small lakes and ponds in Eastern Island by Dumont \& Martens (1995), who did not record the presence of the fish.

A different situation would occur in Juan Fernandez islands, where there are no reports of tropical diseases transmitted by mosquitoes, and the scarce studies on freshwater ecosystems document the presence of native species such as the cyclopoid Paracyclops fimbriatus chiltoni (Brehm, 1936) and the amphipod Orchestia selkirki (Schellenberg, 1935) (González et al. 2008). Thus, these islands might not face the risk of extinction of 
endemic species due to exotic fish introduction, although unfortunately we lack studies about their microinvertebrate communities. Therefore, community studies would be needed to determine if these island have endemic species or similar species to their freshwater counterparts in continental Chile.

In this scenario, we need to assess the species diversity of freshwater ecosystems in Chilean oceanic islands with the aim to determine their ecological role as food resources for aquatic birds or consumers of particulate organic matter (Fernández \& Domínguez 2001). The introduction of exotic fish might suceed in eliminating insects that transmit tropical diseases, but in turn might change the structure and function of ecosystems, as observed in the Loa river (De los Ríos et al. 2010) and central Chilean wetlands (Figueroa et al. 2009). In this regard, the available information on the introduction of the genus Mesocyclops in Costa Rica (Soto et al. 1999) and French Polynesia (Lardeaux 1992, Lardeaux et al. 1992) reveals that this species is an effective biological controller of mosquitoes. Unfortunately, G. affinis is already widespread in continental Chile (Iriarte et al. 2005), although no information is available on its impacts. Thus, it would be interesting and important to compare the long-term effects of $G$. affinis and Mesocyclops on freshwater ecosystems.

\section{LITERATURE CITED}

BREHM V (1936) Mitteilungen von den Forschungsreisen Prof. Rahms. Mitteilung VI. Über die Cladocerenfauna des Titicaca und über einige neue Fundstellen bereits bekannter Copepoden. Zoological Anzeiger 114: 157-159.

DE LOS RÍOS P, SJ ADAMOWICZ \& JDS WITT (2010) Aquatic fauna in the driest desert on earth: First report on the crustacean fauna of the Loa river (Atacama desert, Antofagasta region, Chile). Crustaceana 83: 257-266.

DUMONT HJ \& D VERSCHUREN (1991) Atypical ecology of Pantala flavescens (Fabr.) on Eastern Island (Anisoptera: Libellulidae). Odonatologica 20: $45-51$.
DUMONT HJ \& K MARTENS (1996) The freshwater microcrustacea of Easter Island. Hydrobiologia 325: 83-99.

DYER BS (2000) Systematic review and biogeography of the freshwater fishes of Chile. Estudios Oceanológicos (Chile) 19: 77-98.

FERNÁNDEZ H \& E DOMÍNGUEZ (2001) Guía para la determinación de artrópodos bentónicos sudamericanos. Editorial Universitaria de Tucumán, Tucumán, Argentina.

FIGUEROA R, ML SUÁREZ, A ANDREU, VH RUIZ \& MR VIDAL-ABARCA (2009) Caracterización ecológica de humedales de la zona semiárida en Chile central. Gayana 73: 76-94.

GONZÁLEZ ER, PA HAYE, MJ BALANDA \& M THIEL (2008) Lista de especies de peracáridos de Chile (Crustacea, Eumalacostraca). Gayana 72: 157177.

IRIARTE JA, GA LOBOS \& FM JAKSIC (2005) Invasive vertebrate species in Chile and their control and monitoring by governmental agencies. Revista Chilena de Historia Natural 78: 143-154.

LARDEAUX F, F RIVIERE, Y SECHAN \& BH KAY (1992) Release of Mesocyclops aspericornis (Copepoda) for control of larval Aedes polynesiensis (Diptera: Culicidae) in land crab burrows on an atoll of French Polynesia. Journal of Medical Entomology 29: 571-576.

LARDEAUX F (1992) Biological control of culicidae with the copepod Mesocyclops aspericornis and larvivorous fish (Poeciliidae) in a village of French Polynesia. Medical and Veterinary Entomology 6: 9-15.

LAVAL E (2003) ¿Hubo dengue autóctono en Chile? Revista Chilena de Infectología (Special anniversary edition 2003): 98-99.

LEYSE K, SP LAWLER \& T STRANGE (2005) Effects of an alien fish Gambussia affinis on an endemic fairy shrimp, Linderella occidentalis: Implications for conservation of diversity in fishless waters. Biological Conservation 118: 57-65.

MAGLIULO-CEPRIANO L, MP SCHREIBMAN \& JT TANACREDI (2003) Finfish in the Rano Kau Caldera of Eastern Island. In: Loret J \& JT Tanacredi (eds) Eastern Island, scientific exploration into the world's environmental problem in microcosm: 177-183. Kluwer Academic Publishers, New York, USA.

OLEA P (2003) Primer caso de dengue autóctono atendido en el hospital de enfermedades infecciosas Dr. Lucio Córdova. Revista Chilena de Infectología 20: 129-132.

SCHELLENBERG A (1935) Fauna chilensis, Amphipoden von Chile und Juan Fernandez. Zoologische Jahrbbucher Abteilung fur Systematik 67: 225-234.

SOTO L, S SCHAPER, L ANGULO \& F HERNANDEZ (1999) Mesocyclops thermocyclopoides y el control biológico de Aedes: Ejemplo de un plan de acción comunitaria en Chacarita, Puntarenas. Revista Costarricense de Ciencias Médicas 20: 45-50. 